\title{
KAJIAN INDUSTRI 4.0 UNTUK PENERAPANNYA DI INDONESIA
}

\author{
STUDY ON INDUSTRY 4.0 \\ FOR THE APPLICATION IN INDONESIA \\ Suharman $^{1)}$ dan Hari Wisnu Murti ${ }^{2}$ \\ ${ }^{1,2)}$ Pusat Penelitian dan Pengembangan Teknologi Industri dan Kekayaan Intelektual \\ Kementerian Perindustrian RI, Jl. Jend. Gatot Subroto Kav.52-53 Jakarta Selatan \\ ${ }^{*}$ Penulis korespondensi : suharman.hadi@gmail.com \\ Diterima: 15012019 \\ DOI Number : 10.30988/jmil.v3i1.59

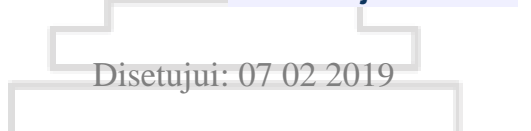 \\ Dipublikasi: 15032019

\section{Abstract} \\ The implementation of concept Industry 4.0 in Indonesia has been studied in this paper. The study \\ was motivated after the launcing of Making Indonesia 4.0 by the President of the Republic of \\ Indonesia in April 2018. The study aims to study the concept of IR 4.0 for its implementation in \\ Indonesia. Methods include collecting various references with industry 4.0 keywords, applying \\ information technology, pharmaceutical industry and manufacturing industries. The results of the \\ study concluded that industry 4.0 was an era that empowered the role of manufacturing digitalization \\ and supply networks that involved the integration of digital information from various sources and \\ locations to drive manufacturing and distribution physically. It is found that, There are five main \\ technologies for IR 4.0, namely Artificial Intelligence (AI), Internet of Things (IoT), Wearable \\ Technology (WT), Advanced Robotic (AR) and 3D Printing (3DP). Each component of technology \\ can be used in various industries and manufacturing. The implementation of IR 4.0 would likely \\ provide more benefits and advantages such as increase effieciency and effectivty in manufacturing \\ industries.
}

Keywords: Concept of IR 4.0, application of information technology, manufacturing industry.

\section{Abstrak}

Telah dilakukan kajian yang mempelajari konsep Industri 4.0 (IR.4.0)untuk penerapannya di Indonesia. Kajian dilatar belakangi oleh dicanangkannya making Industri 4.0 oleh Presiden RI pada bulan April 2018. Kajian bertujuan mempelajari konsep IR 4.0 untuk implementasinya di Indonesia. Metode meliputi pengumpulan berbagai referensi dengan kata kunci industry 4.0, penerapan teknologi informasi, industru farmasi dan industry manufaktur. Selanjutnya referensi tersebut dianalisis dan diskripsi sehingga menghasilkan suatu ringkasan. Hasil kajian menyimpulkan bahwa industry 4.0 merupakan era yang memberdayakan peran digitalisasi manufaktur dan jaringan suplai yang melibatkan integrasi informasi digital dari berbagai sumber dan lokasi untuk menggerakkan manufaktur dan distribusi secara fisik. Terdapat lima teknologi utama IR 4.0, yaitu artificial Intelligence (AI), Internet of Things (IoT), Wearable Technology (WT), Advanced Robotic (AR) dan $3 D$ Printing (3DP). Masing-masing komponen teknologi dapat dimanfaatkan pada berbagai industry dan manufaktur. Pemanfaatan IR 4.0 diyakini akan memberikan manfaat dan keuntunganyang lebih banyak (misalnya kinerja menjadi lebih efektif dan lebih efisien).

Kata kunci : Konsep IR 4.0, penerapan teknologi informasi, industry manufaktur. 


\section{PENDAHULUAN}

Tahun 2017 merupakan tahun pertumbuhan ekonomi global terbesar yang terjadi sejak tahun 2011. Hal ini disebabkan karena setiap industri manufaktur melakukan percepatan dan pertumbuhan produktivitasnya. Kemajuan pertumbuhan ekonomi dan industri yang terjadi tidak terlepas dari pengaruh kemajuan teknologi. Era teknologi yang saat ini dijalankan adalah pemberdayaan peran integrasi digital pada sektor industri yang selanjutnya dikenal sebagai Era Industri 4.0.

Era industry 4.0 atau revolusi industri ke empat (IR 4.0) adalah era industri transisi. IR 4.0 memberdayakan peran digitalisasi manufaktur pada jaringan suplai yang melibatkan integrasi informasi dari berbagai sumber dan lokasi untuk menggerakkan manufaktur dan distribusi secara fisik. Integrasi teknologi informasi dan teknologi operasi ini ditandai dengan konetivitas antara peran fisik ke digital dan ke fisik. IR 4.0 menerapkan Internet of Things (IoT) dan teknologi fisik pada kegiatan analisis, manufaktur, robotik, komputasi canggih, artificial intelligence, teknologi kognitif, advance materials dan augmented reality dalam melaksanakan siklus operasi bisnis [1].

Transisi menuju IR 4.0 adalah sebuah keharusan bagi industri. Peralatan, produk, dan pabrik yang berbasis "smart" akan mentransformasikan perusahaan dalam menjalankan bisnis baik ke dalam maupun terhadap supplier dan konsumer. Digitalisasi operasi dan proses lain memungkinkan dijalankannya fungsi "predictive maintenance".

Dalam kaitannya dengan IR 4.0, World Economic Forum (WEF) menyusun empat segmen dalam mendefinisikan kesiapan negara-negara dunia dalam menghadapi tantangan tersebut. Kesiapan struktur produksi dan kesiapan struktur ekonomi menjadi parameter dalam pengklasifikasian tersebut. Menurut [2], Indonesia berada di kelas negara nascent countries yang menunjukkan struktur produksi dan struktur ekonomi yang masih lemah. Malaysia dan Singapura berada di kelas leading countries bersama Amerika Serikat, Perancis, Republik Rakyat Tiongkok, Kerajaan Ingris, dan Jepang yang kuat struktur produksi dan struktur ekonominya [2]. Kesiapan aspek produksi tidak terlepas dari kemampuan menguasai teknologi. Kekuatan dan sistem teknologi akan mempengaruhi posisi pelaku industry dalam persaingan bisnis industri manufaktur [3].

Saat ini negara-negara di dunia mulai berkompetisi dalam pemanfaatan teknologi pada setiap sektor industrinya [4]. Kesadaran posisi Indonesia yang lemah strukrur ekonomi dan produksinya tersebut penerapan IR 4.0 di Indonesia menjadi suatu hal yag penting dan strategis. Oleh karena itu Presiden RI mencanangkan Making Indonesia 4.0.

Mempelajari Konsep Industri 4.0 untuk penerapannya di Indonesia menjadi suatu keharusan, sebab jika tidak maka industry dan manufaktur di Indonesia tidak akan dapat bersaing dengan industry dan manufaktur di negara-negara lain di dunia.

Kajian ini bertujuan untuk mendapatkan gambaran dan pemahaman tentang IR 4.0 untuk penerapannya di Indonesia.

\section{METODE PENELITIAN}

Kajian IR 4.0 untuk penerapannya di Indonesia ini dilakukan dengan cara mengumpulkan referensi terkait dengan kata kunci industry 4.0, teknologi industry, penerapan technology informasi, industry farmasi dan industry manufaktur. Referensi dari keempat kata kunci ini selanjutnya (diolah) dipelajari, dipahami dan dianalisa serta dicari hubungan keterkaitan satu dengan 
lainnya untuk selanjutnya didiskripsikan dan diambil kesimpulan. Contoh penerapan industry 4.0 ditampilkan sebagai pendukung untuk lebih memudahkan dalam memberikan pemahaman. Hasil studi ini selanjutnya dapat dijadikan sebagai benckmark bagi pembangunan dan pengembangan industry dan manufaktur di Indonesia. Pola pikir kajian seperti pada Gambar 1.

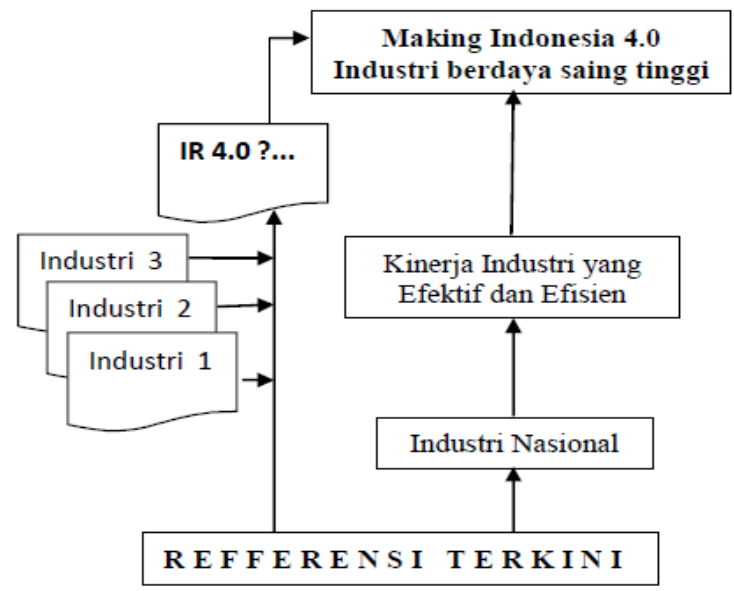

Gambar 1. Pola pikir kajian Industry 4,0 untuk penerapannya di Indonesia.

\section{HASIL DAN PEMBAHASAN}

\section{Revousi Industri Empat (IR 4.0)}

IR 4.0 adalah era industrialisasi yang saat ini sedang menjadi arah tujuan bagi pembangunan dan pengembangan sektor industry dan manufaktur dunia. Istilah IR 4.0 tidak terlepas dari tiga era industri yang telah terjadi sebelumnya.

Revolusi industri pertama ditandai dengan diperkenalkannya mesin uap, revolusi industri kedua ditandai dengan produksi masal. Revolusi industri ketiga ditandai dengan pemanfaatan teknologi elektronik dan teknologi informasi disertai penggunaan mesin otomasi.

Istilah IR 4.0 pertama kali dipublikasikan pada tahun 2011 dengan istilah "Industrie 4.0" oleh sebuah asosiasi yang beranggotakan kalangan penguasaha, politisi, dan akademisi yang mengajukan gagasan penguatan kompetisi industri manufaktur di Jerman [6, 7]. Negara Jerman memiliki kepentingan yang besar terkait hal ini karena IR 4.0 menjadi bagian dari kebijakan rencana pembangunannya yang disebut High-Tech Strategy 2020. Kebijakan tersebut bertujuan mempertahankan Jerman untuk selalu menjadi yang terdepan di dunia manufaktur $[7,8]$.

\section{Konsep Dasar IR 4.0}

Era IR 4.0 pada prinsipnya adalah memberdayakan peran digitalisasi manufaktur dan jaringan suplai yang melibatkan integrasi informasi dari berbagai sumber dan lokasi. Pemanfaatan informasi digital tersebut digunakan untuk menggerakkan manufaktur dan distribusi fisik. Integrasi antara teknologi informasi dan teknologi operasi ini ditandai dengan koneksi perpindahan lompatan peran fisik ke digital ke fisik.

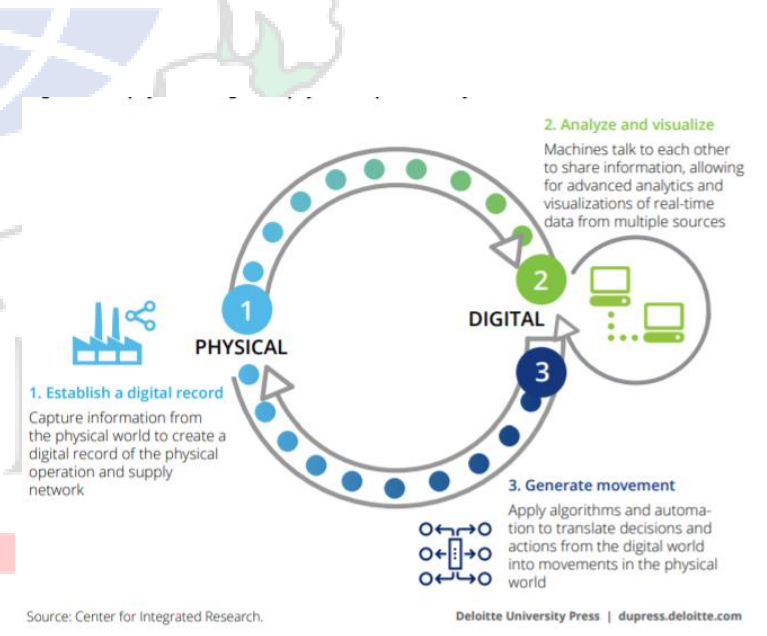

Gambar 2. Lompatan Fisik - Digital - Fisik pada Industri 4.0 [9]

IR 4.0 memanfaatkan Internet of Things (IoT), teknologi fisik dan digital untuk keperluan analisis, manufaktur, robotik, komputasi canggih, artificial intelligence, teknologi kognitif, advance materials dan augmented reality dalam menjalankan siklus operasi bisnis [9]. Framework kerja dari industri 4.0 seperti pada gambar 3 . 
Secara umum pelaksanaan IR 4.0 tidak terlepas dari pengelolaan data dan analisis sebagai inti teknologi. Pengelolaan data dan analisis tersebut meliputi digitalisasi dan integrasi rantai pasok secara horizontal dan vertikal. Komponen teknologi yang digunakan adalah IoT platform, Cloud Computing, dan Mobile Devices sebagai digitalisasi produk dan layanan. Komponen teknologi yang digunakan Augmented reality, multilevel costumer interraction and costumer profilling, big data analytics and advanced algorithm dan smart sesnsor sebagai pelaksanaan bisnis secara digital dan layanan konsumer yang berkemajuan.

Teknologi yang digunakan diantaranya $3 D$ Printing, Location Detection Technology, Advanced Human-Machine interfaces, dam authentification and fraud detection.

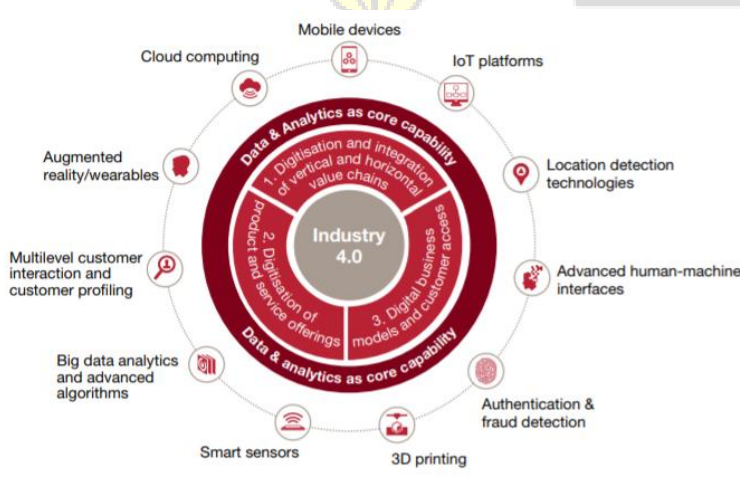

Gambar 3. Framework Kerja IR 4.0 [10]

[8] dalam [11] menyebutkan ada tiga hal dasar terkait teknologi IR 4.0 dalam sebuah organisasi indusrtri yang terintegrasi yaitu 1 ). Integrasi horizontal antara jaringan yang melibatkan integrasi sistem teknologi informasi beberapa divisi pada proses manufaktur dan perencanaan bisnis yang memberikan informasi tentang neraca materi dan neraca energi di setiap divisi organisasi serta hubungan antara perusahaan dengan perusahaan lain. 2). Integrasi digital end to end yaitu sistem teknologi informasi yang menyediakan platform end to end pada setiap value chain dari pengembangan produk sampai sistem manufaktur engineering, production, dan services. Analisa terpadu system, pendekatan sistem engineering dan informasi dari berbagai displin bidang keilmuan dipersyaratkan dalam sistem ini. 3). Sistem pada manufaktur yang terintegrasi secara hierarki vertikal yaitu dalam setiap level hierarki (dari tingkat kontrol, engineering, hingga direksi) terintegrasi secara end to end.

Terdapat 5 teknologi mendasar sebagai fundamental penguasaan teknologi terhadap daya saing suatu negara, industry manufaktur dan value chain proses produksi. [4] menyebutkan kelima teknologi tersebut adalah: 1) Artificial Intelligence (AI), 2) Internet of Things (IoT), 3) Wearables Technology (Augmented Reality - AR and Virtual Reality - VR), 4) Advanced Robotics, 5) $3 D$ printing. Kelima teknologi Industri 4.0 ini mencakup keseluruhan arus logik (logical layer), arus konektivitas (connectivity layer) dan arus fisik (physical layer) sebagaimana pada gambar 5 .

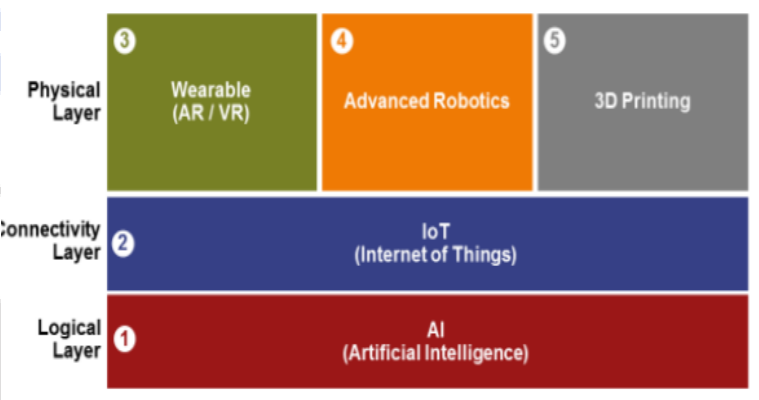

Gambar 5. Lima teknologi dasar Industry 4.0 di bidang produksi dan manufaktur [4].

Artificial Intelligence (AI) adalah kecerdasan buatan, yaitu sebuah kondisi ketika sebuah mesin mampu meniru fungsi kognitif yang dikaitkan dengan pikiran manusia [12]. Dekade 2000 - 2017 merupakan dekade yang penting dalam perkembangan kecerdasan buatan, yang ditandai dengan semakin baiknya algoritma kecerdasan buatan yang ada, yang kemudian lebih dikenal sebagai Deep Learning. Konsep deep learning meniru mekanisme otak manusia bekerja yang dikombinasikan dengan kemampuan menerima data yang besar. Kedua hal ini sangat dimungkinkan oleh kemampuan 
komputasi pararel yang semakin baik, tidak hanya terfokus pada satu mesin atau

pembelajaran itu sendiri menjadi semakin cepat.

\section{From Traditional Value Chains..}

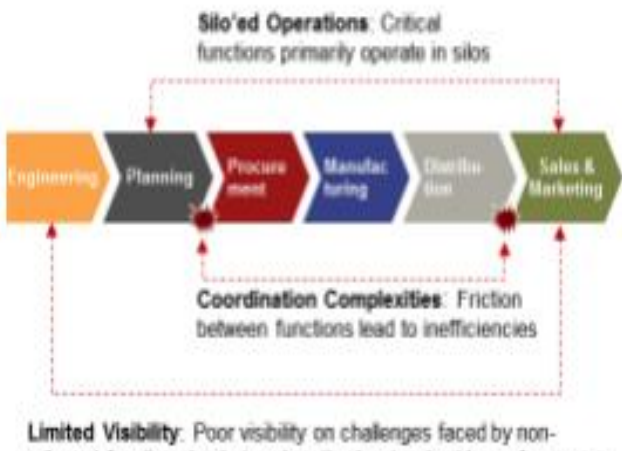

adjacent functions leads to sub-optenal network-wide performance

\section{...to Tightly Integrated Value Networks}

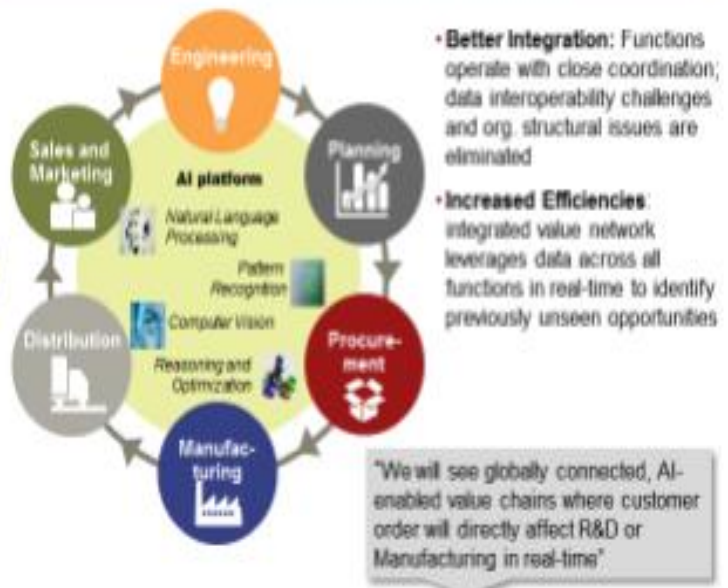

Gambar 6. Perubahan paradigma dan peningkatan efisiensi pengambilan keputusan melalui implementasi AI.

prosesor, namun kelompok-kelompok mesin sebagaimana otak manusia dikonstruksikan. Pada era ini penggunaan kecerdasan buatan mulai digunakan dan diterapkan dalam proses bisnis misalnya mulai dikenal teknologi robotic process automation yang merupakan mesin untuk menggantikan tugastugas proses pelaporan, akuntansi, dan lainlain di lingkungan industri.

Seiring dengan meningkatnya kekuatan komputasi dan semakin tidak terbatasnya kemampuan untuk menyimpan informasi melalui big data, pelaku industri semakin yakin bahwa era paska 2017, kecerdasan buatan akan semakin besar peranannya di berbagai industri, dan semakin mampu untuk terlibat dalam berbagai keputusan operasional dan strategis.

Kemampuan belajar dari data yang begitu banyak dan algoritma berfikir yang semakin baik akan semakin meningkatkan kualitas pengambilan keputusan dari mesin yang ada, sementara peningkatan yang sangat pesat dari kemampuan komputasi akan membuat kecepatan kecerdasan buatan dan proses
Pada IR 4.0 fungsi utama kecerdasan buatan lebih kepada menghilangkan batasbatas value chain tradisional (Gambar 5). Kecerdasan buatan mampu mempercepat pengambilan keputusan, menjamin transparansi pada setiap komponen value chain yang ada (pertukaran data dan analisa dapat dilakukan secara real time), melihat pola-pola yang ada berdasarkan data yang sangat besar, dan pengambilan keputusan pada saat yang tepat [4].

Di masa depan pemanfaatan mesin untuk menjalankan peran kecerdasan manusia akan semakin inklusif dilengkapi dengan kemampuan pengambilan keputusan dan perasa emosi [13]. Hal ini merupakan pengantar masuknya teknologi industri 4.0 [14].

[4] menyebutkan beberapa contoh penggunaan teknologi AI pada value chain produksi hingga pemasaran misalnya ; sales and marketing, membantu untuk melakukan personalisasi penawaran, kriteria dan spesifikasi produk yang unik untuk segmen dan pelanggan tertentu, prediksi keberhasilan 
penjualan dan probabilitas konversi pelanggan ; distribution, membantu meningkatkan efisiensi dan efektivitas distribusi melalui analisa data yang besar, menentukan biaya untuk melayani suatu segmen dan pelanggan tertentu, rute yang paling optimal kepada pelanggan, evaluasi biaya logistik ; manufacturing, melakukan personalisasi produk, pengambilan keputusan dan analisa data-data produksi untuk perbaikan proses produksi, prediksi perawatan, down-time lini produksi dan mempersiapkan rencana kontigensinya.

IoT merupakan sebuah ekstensi konektivitas jaringan dan kemampuan komputasi ke objek, perangkat, sensor, dan item yang biasanya tidak terkomputerisasi. Peralatan ini membutuhkan intervensi orang untuk menampilkan konektivitas guna pengumpulan data jarak jauh, analisis, dan kegiatan manajemen [15].

Teknologi IoT memuat setidaknya tiga elemen yang berkembang secara terpisah yaitu teknologi konektivitas melalui internet, teknologi sensor, dan teknologi penyimpanan data (cloud) [4].

Teknologi IOT yang semakin maju, di bidang industri, produksi dan manufaktur, telah membawa manfaat berupa ; peningkatan kualitas akses, informasi tersedia dimana saja dan kapan saja, sehingga pengambilan keputusan dapat dilakukan dengan cepat, biaya murah sehingga produktivitas meningkat ; kemampuan monitor dan pengendalian, teknologi sensor yang semakin maju dan terpasang di seluruh komponen produksi akan mengurangi berbagai resiko, mengurangi kerusakan, menurunkan biaya, dan mengoptimalkan penggunaan aset. Pengendalian terhadap keseluruhan proses produksi dan akses akan lebih mudah dilaksanakan ; deep learning \& inisights, melalui teknologi sensor penyimpanan data (cloud) dan besarnya jumlah data yang dihasilkan dapat menjadi bahan bagi sistem kecerdasan buatan untuk memperbaiki proses produksi, meningkatkan kualitas produk, bahkan memberikan peningkatan dalam siklus inovasi.

AR adalah sistem robot yang mampu secara otomatis bekerja berdasarkan fungsi penciptaannya. [16] menerangkan, sistem komunikasi AR menjalankan Human Robot Interaction, sebagaimana tergambar pada diagram 7.

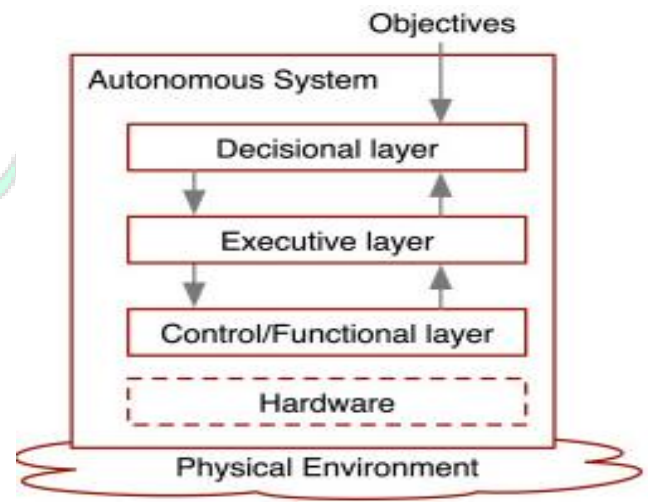

Gambar 7. Sistem Human Robot Interaction pada AR [16]

Decisional Layer adalah sistem yang bertugas menerima informasi dari sistem lain (operator) dan menghasilkan beberapa rencana sesuai dengan representasi abstrak dari sistem dan lingkungannya sebagai fungsi perencanaan, pembelajaran, atau penetapan tujuan [17].

Excecutive layer bertugas mengubah rencana yang dikirim oleh lapisan putusan, menjadi fungsi untuk tingkat fungsional; control/functional layer bertanggung jawab atas kontrol umpan balik loop kopling sensor untuk - aktuator, fasilitas persepsi dan perhitungan lintasan.

[4] menyebutkan, penggunaan teknologi AR di Industri 4.0 akan membawa manfaat yang besar terhadap peningkatan produktivitas dan penurunan biaya atau efisiensi, keamanan lingkungan kerja, hingga konsistensi kualitas, serta fleksibilitas dalam proses produksi. Dalam hal peningkatan produktivitas, robot akan menjamin output secara cepat dan terus menerus melalui teknologi yang lebih baik. 
WT adalah perangkat teknologi yang dapat dipakai oleh konsumen untuk melacak informasi yang berkaitan dengan aktivitas (misalnya kesehatan dan kebugaran). Teknologi gadget atau lainnya dapat dipakai untuk mengambil foto dan mensyinkronkan dengan perangkat seluler [18].

3D Printing (3DP) dikenal sebagai manufaktur aditif. Teknologi ini dapat digunakan untuk membuat komponen dengan cepat dalam bentuk kompleks apa pun dengan penggunaan material secara akurat melalui pemodelan padat sesuai dengan model Computer-aided design (CAD) atau computed tomography (CT) scan di bawah kendali computer [19].

Keberadaan 3DP memungkinkan kemajuan yang besar dalam pengembangan peralatan medis, bahan implan, pencetakan sel, persiapan model organ, dan pencetakan langsung di situs cacat. Teknologi 3DP bahkan dapat membawa kemungkinan baru untuk membangun jaringan atau organ bionik [20].

\section{Penerapan Industri 4.0}

IR 4.0 saat ini telah banyak diterapkan di Industri Farmasi [21] dan telah mendapatkan dukungan dari para stakeholder untuk menjamin kemanan dan perlindungan masyarakat [22]. Industri farmasi pada awalnya masih menerapkan sistem batch manufacturing yang bercirikan mult-step, kaku, dan dengan peralatan skala besar.

Penerapan IR 4.0 telah mengubah konsep batch manufacturing menjadi konsep continous yang sederhana dan akurat [21]. Continous manufacturing melibatkan system transportasi yang baik sehingga dapat menghemat waktu dan mengurangi faktor kesalahan manusia karena semuanya terintegrasi dan terkontrol [21].

Perbedaan mendasar antara sistem batch manufactur dengan continous manufactur pada industri farmasi terlihat seperti pada gambar 7. [21] menyebutkan bahwa secara umum manufaktur obat terdiri dari lima unit operasi yaitu sintesis, kristalisasi, pencampuran, granulasi dan kompaksi produk dengan coating. Konsep continous manufactur tetap menjalankan tahapan tahapan produksi, tetapi terintegrasi dengan proses sistem kontrol yang memungkinkan proses berjalan secara kontinu dan terkendali sehingga membutuhkan waktu yang lebih singkat dan alat-alat yang digunakan bervolume lebih kecil. Pemanfaatan 3DP berbasis kontrol digital terhadap material juga sudah dimanfaatkan untuk menghasilkan obat dengan geometri yang lebih spesifik [23].

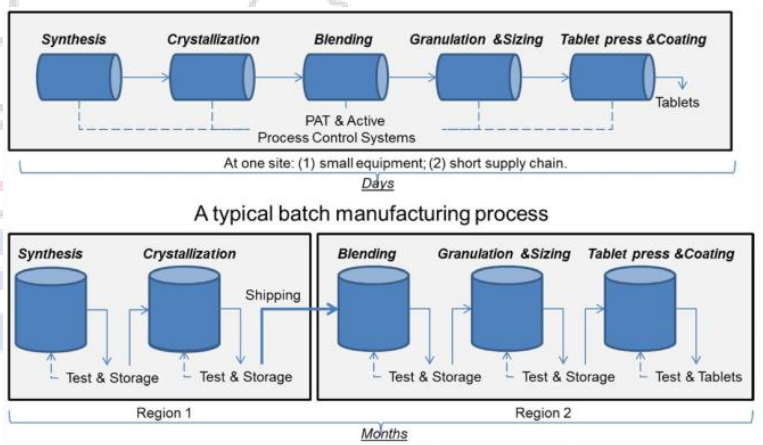

Gambar 8. Simulasi perbedaan manufaktur batch dan manufaktur kontinu pada industri farmasi [21].

Proses manufaktur kontinu telah mengadopsi konsep satuan unit operasi yang saling bersambungan mulai dari sintesa, kristalisasi, pencampuran, granulasi dan pelapisan dengan kapsul. Di L.B. Bohle's Technology Center di Ennigerloh Jerman telah dilakukan pengembangan produk farmasi yang portable, miniatur dan modular berbasis dosis sehingga memungkinkan konsumer dapat menentukan sendiri produksinya dan menjalankan proses kontrol system secara terintegrasi [24].

[25] menyebutkan diantara keuntungan manufaktur kontinu adalah proses mengintegrasikan semua tahapan produksi dari mulai produksi hingga sistem kontrol 
yang baik dengan biaya yang murah serta dengan kecepatan produksi yang lebih baik. Jika ditinjau perbandingannya dengan sistem batch, maka dalam waktu 24 jam yang sama sistem kontinu mampu memproduksi obat lebih banyak. Demikian pula ditinjau dari kualitas produk, sistem kontinu lebih terkontrol karena waktu tinggal dan proses antara yang bisa diminimalisasi. Peralatan yang digunakan juga relatif lebih kecil sehingga maintenance lebih mudah. Demikian pula mampu mengurangi kemungkinan produk terkontaminasi karena produksi terjadi secara kontinu dalam satu line produksi yang terintegrasi.

\section{Analisa}

Dari berbagai kajian yang dilakukan dapat disimpulkan bahwa terdapat lima teknologi utama IR 4.0, yaitu Artificial Intelligence, Internet of Things, Wearable Technology, Advanced Robotic dan 3D Printing. Kasus penggunaan lima teknologi utama IR 4.0 tersebut dapat digambarkan penerapannya pada industry farmasi sebagai berikut;

\section{Artificial Intelligence (AI)}

Pada industri farmasi sifat-sifat formulasi ditentukan tidak hanya oleh rasio di mana bahan-bahan digabungkan tetapi juga oleh kondisi pengolahan. Meskipun hubungan antara tingkat bahan, kondisi proses dan kinerja produk dapat diketahui secara jelas, namun hubungan-hubungan tersebut pada umumnya tidak dapat dikuantifikasi. Formulator cenderung menggunakan teknik statistik untuk memodelkan formula dan mengandalkan respon permukaan untuk mekanisme optimasi. Optimasi semacam ini sering tidak tepat atau bahkan dapat keliru terutama jika formulanya kompleks [25].

Kemajuan ilmu matematika dan ilmu komputer telah mengarah pada pengembangan pemodelan alternatif dan teknik penambangan data yang bekerja dengan sumber data yang lebih luas. AI adalah sistem pemrosesan otak manusia yang ditirukan pada mesin [26].
Konsep AI pada neural network adalah layaknya sistem saraf pada manusia yang meniru konsep Multi Layer Perception. Konsep ini terdiri dari neuron identik yang saling terhubung dan terorganisir dalam lapisan. Output dalam satu lapisan menjadi input di lapisan berikutnya.

Aliran data ke jaringan melalui lapisan input mellalui lapisan tersembunyi dan akhirnya keluar sebagai output. Untuk setiap neuron (input) memiliki bobot terkait yang mendefinisikan informannya yang kemudian difungsikan dengan fungsi transformasi (disebut transfer atau fungsi aktivasi) sebelum diteruskan ke neuron lain. Mekanisme peran neural network seperti pada gambar 9.

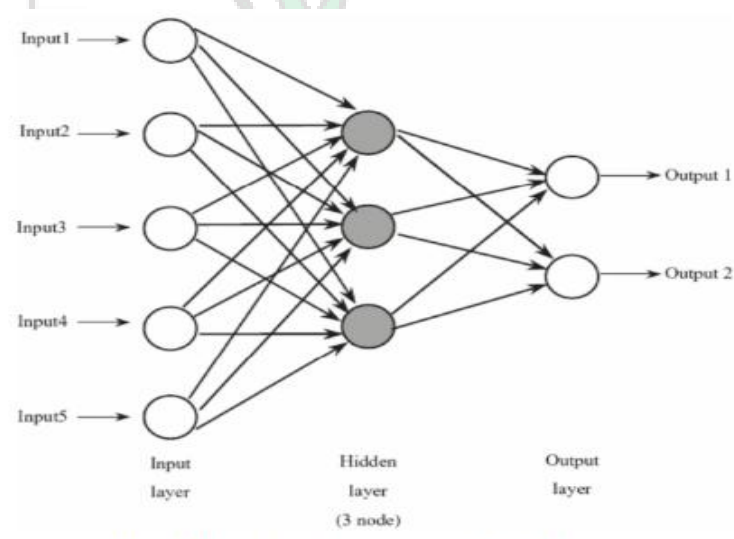

Gambar 9. Diagram multilayer neural network [26].

Konsep Neural Network merupakan konstruksi matematika yang mampu menghubungkan antar data. Neural Network tidak membuat asumsi tentang bentuk fungsional dari hubungan, melainkan hanya menghasilkan dan menilai berbagai model untuk menentukan satu yang paling sesuai dengan data yang diberikan.

Model yang dihasilkan oleh jaringan saraf ini memungkinkan untuk diselidiki dengan mudah. Kemampuannya meningkat secara substansial dengan menggabungkannya dengan teknologi lain. Sebagai contoh dalam sebuah database, mesin bekerja kemudian muncul case yang berbeda dengan formula 
yang ditetapkan maka akan menghasilkan sense yang menginformasikan kepada user untuk diambil tindakan.

\section{Internet of Things (IoT)}

Penerapan IoT untuk manufaktur dan manajemen rantai pasok telah menjadi populer pada berbagai industri. Peralatan yang terhubung, tracking manusia dan barang, manajemen siklus hidup sampel, dan pemantauan rantai dingin adalah salah satu aplikasi IoT pada industry. Inti dari IoT adalah adanya mekanisme akuisisi data pada level Programmable Logic Control (PLC) dan sistem supervisor, kemudian data terproses dalam Cloud Computing yang menjadikan terkoneksi dengan Management Excecution System (MES) dan ERP (manajemen puncak) [27]. Mekanisme manajemen IoT dijelaskan pada gambar 10.
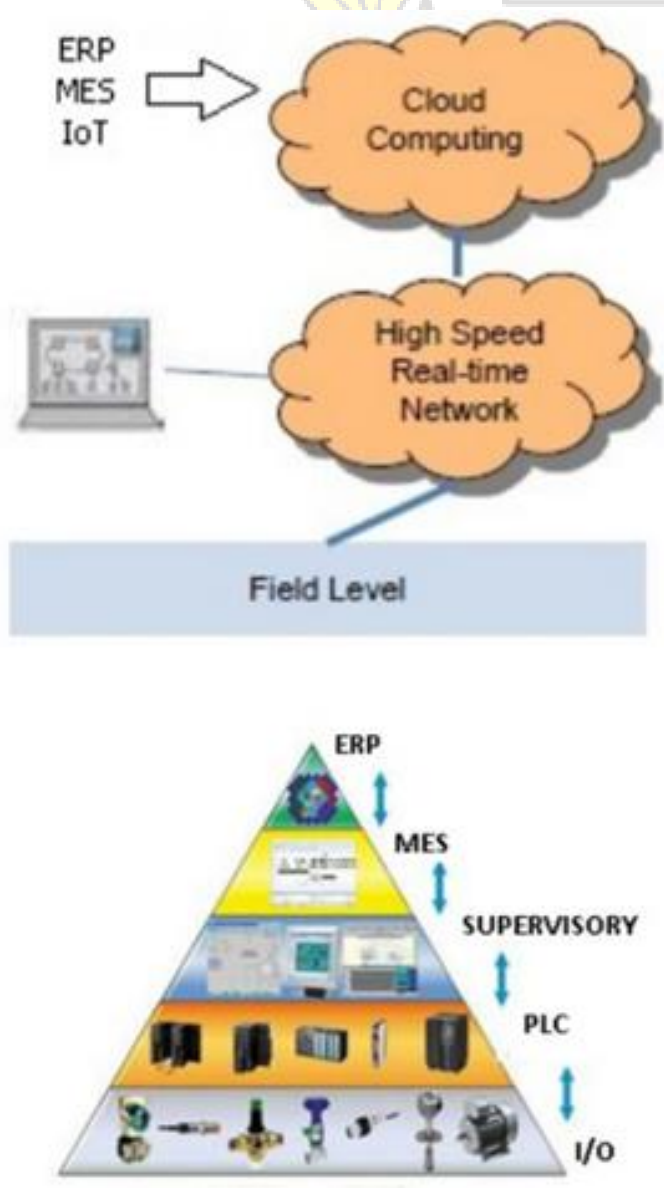

Gambar 10. Model Manajemen IoT [27]

Beberapa keuntungan dari penggunaan IoT adalah smart equipment yaitu pengumpulan data operasional dan status (run time, suhu, data kesiapan operasi, data kebersihan, data pemeliharaan, dll) sehingga didapatkan informasi real time terkait penjadwalan kegiatan secara dinamis, running analitik yaitu data digunakan untuk memprediksi kapan peralatan akan dimatikan [28] sensor yaitu mengumpulkan meta data untuk analisis dalam mengidentifikasi dan mengurangi penyebab variabilitas proses dan peningkatan produksi [29], visibilitas yaitu mengetahui pergerakan material dengan teknologi pelacakan dan pemantauan [26].

\section{Wearable Technology (WT)}

Dalam bidang kesehatan, WT telah diterapkan pada pengujian cairan tubuh dan penyaluran obat dalam jaringan. Saat ini, chip didalam pil yang dulu hanya ada dalam fantasi, melalui teknologi Ingestible Event Marker (IEM) telah berhasil menjadi kenyataan. IEM dengan ukuran sebutir pasir, berisi sebuah Integrated Circuit yang terdapat anoda dan katoda. Setelah tablet atau pil yang berisi sensor mencapai perut, tablet ini diaktifkan oleh asam lambung. Sinyal listrik yang dihasilkan asil menghasilkan tanda spesifik yang dideteksi dengan sebuah patch yang dapat dikenakan pada pasien sehingga data yang dihasilkan terbatas pada tubuh pengguna. Sensor yang telah tertelan mengkomunikasikan informasi sekitar tujuh menit setelahnya dimana mereka menjadi tidak aktif dan dihilangkan dalam kotoran atau sedang diserap dalam tubuh. Teknologi ini dikembangkan oleh FDA di tahun 2012 dan di 2017 diberikan nama ABILIFY MYCITE [30].

\section{Advanced Robotic (AR)}

Robot dengan logika telah dikembangkan dan digunakan di bidang pengendalian proses 
yang memungkinkan aturan untuk diekspresikan dalam bentuk linguistik sederhana IF (A) THEN (B) dengan fungsi keanggotaan yang ditetapkan. Contoh sederhana adalah pemanas kipas yang diatur oleh 4 aturan. Aturan-aturan ini mempetakan ke empat set fuzzy COLD, COOL, WARM dan HOT. Jadi, misalnya jika suhu ruangan adalah $18^{\circ} \mathrm{C}$ maka menurut peraturan 2 kecepatan kipas adalah sedang, dengan tingkat kebenaran 0,7 dan oleh peraturan 3 kecepatan kipas rendah dengan tingkat kebenaran 0,3. Proses de-fuzzification ini memungkinkan dicapainya kecepatan yang tepat dari kecepatan kipas [26]. Fuzzy logic dari robot yang merepresentasikan temperatur ruang seperti pada Gambar 11.

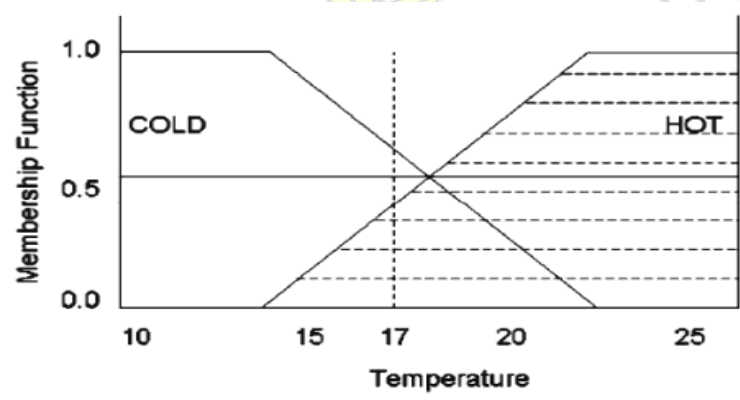

Gambar 11. Fuzzy logic dari robot untuk merepresentasikan temperatur ruang [26].

\section{D Printing (3DP)}

3DP memungkinkan penentuan komposisi obat dan eksipien diproduksi secara tepat dan memungkinkan dilakukannya perubahan desain, manufaktur. Pengembangan obat fase awal dapat dipercepat dengan menggunakan 3DP untuk menghasilkan formula dengan fleksibilitas dosis yang baik dengan biaya rendah.

3DP dapat mendukung pengembangan formulasi obat karena memiliki kemampuan menghasilkan iterasi produk secara cepat untuk pengujian dan kompatibilitas eksipien. 3DP dapat mempercepat penyediaan obat yang diproduksi secara khusus [31].

[32] melakukan percobaan dua isomer aminosalicylate yang digunakan dalam pengobatan penyakit radang usus (IBD), asam 5-aminosalicylic (5-ASA, mesalazine) dan 4-aminosalicylic acid (4-ASA), dijadikan sebagai obat model. Filamen polivinil alkohol (PVA) yang diproduksi secara komersial diisi dengan obat dalam larutan obat etanol. Pembuatan obat akhir sebesar $0,06 \% \mathrm{~b} / \mathrm{b}$ dan $0,25 \% \mathrm{~b} / \mathrm{b}$ untuk 5 -ASA dan 4-ASA. Tablet berdiameter $10,5 \mathrm{~mm}$ dari kedua PVA / 4-ASA dan PVA / 5-ASA kemudian dicetak menggunakan printer 3D FDM, dengan memvariasikan berat dan densitas dari tablet yang dicetak. Pencetakan 3D FDM terbukti menjadi proses yang efektif untuk pembuatan obat, 5-ASA.

Pekerjaan tersebut menunjukkan peran potensial dari FDM 3DP sebagai metode alternatif yang efisien dan murah terhadap pembuatan dosis obat. Aktifitas modifikasi formulasi disimulasikan pada gambar 12 .

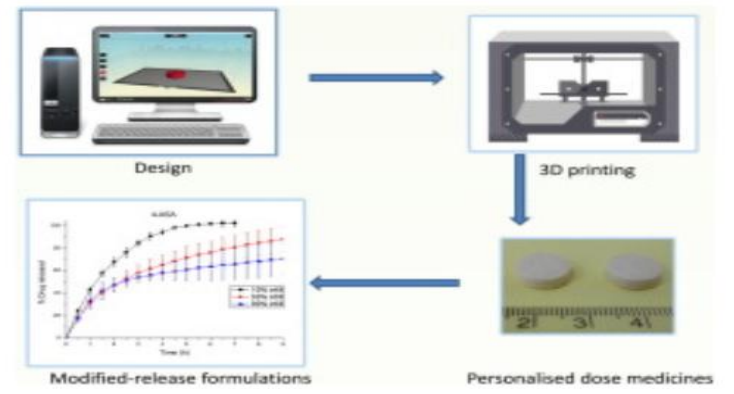

Gambar 12. Mekanisme penelitian [32]

Dari hasil kajian yang dilakukan terhadap berbagai refferensi terkait dengan IR 4.0 maka diperoleh gambaran tentang penerapan IR 4.0 terutama pada industry farmasi dan manufaktur. Industri farmasi dan industry manufaktur dapat menjadi banckmark bagi industry lainnya, oleh sebab itu dengan mengacu pada IR 4.0 Industri di Indonesia dapat menerapkannya sesuai dengan kebutuhan. Penerapan IR 4.0 dapat meningkatkan kinerja secara lebih efektif dan efisien.

\section{KESIMPULAN}

IR 4.0 memberdayakan peran digitalisasi manufaktur dan jaringan suplai yang Page $\mid 10$ 
melibatkan integrasi informasi digital dari berbaga sumber dan lokasi untuk menggerakkan manufaktur dan distribusi secara fisik.

Terdapat lima teknologi utama IR 4.0, yaitu Artificial Intelligence (AI), Internet of Things (IoT), Wearable Technology (WT), Advanced Robotic (AR) dan 3D Printing (3DP). Masing-masing komponen teknologi telah dimanfaatkan pada industri farmasi dan manufaktur.

Logika AI dapat mengidentifikasi dan mengendalikan formulasi obat. IoT dapat menghubungkan seluruh alat dan komponen manufaktur dalam satu jaringan komunikasi. WT dapat diterapkan pada alat pengidentifikasin secara real time kontinu. AR dapat dimanfaatkan untuk mengontrol temperatur system dan alat-alat teknologi. 3DP dapat dimanfaatkan untuk simulasi dalam melakukan formulasi obat dan simulasi produksi manufaktur serta customized order dari konsumen.

\section{DAFTAR PUSTAKA}

[1] K. Bock, W. F. A. K. J.-P. Nickel, and H. Meincke. (2017, 19 Agustus 2018). Chemistry 4.0 : Growth through innovation in a transforming world. Available:

https://www2.deloitte.com/content/da $\mathrm{m} /$ Deloitte/global/Documents/consum er-industrial-products/gxchemistry\%204.0-full-report.pdf

[2] "Readiness for the Future of Production Report " in World Economic Forum, Switzerland, 2018.

[3] A. Andreoni, "Industrial ecosystems and policy for innovative industrial renewal: A new framework and emerging trends in Europe," Sitra working paper2017.

[4] A. Kearney, "Roadmap Implementasi Industry 4.0 di Indonesia," ed.
Jakarta: Kementerian Perindustrian, 2017.

[5] K. Perindustrian, "Rencana Induk Pembangunan Industri Nasional 2015-2035," ed. Jakarta, Indonesia: Pusat Dokumentasi Publik, 2015. H. Kagermann, W.-D. Lukas, and W. Wahlster, "Industrie 4.0: Mit dem Internet der Dinge auf dem Weg zur 4. industriellen Revolution," VDI nachrichten, vol. 13, 2011.

M. Hermann, T. Pentek, and B. Otto, "Design Principles for Industrie 4.0 Scenarios: A Literature Review. Technische Universitat Dortmund," working paper2015.

[8] H. Kagermann, J. Helbig, A. Hellinger, and W. Wahlster, Recommendations for implementing the strategic initiative INDUSTRIE 4.0: Securing the future of German manufacturing industry; final report of the Industrie 4.0 Working Group: Forschungsunion, 2013.

[9] M. Cotteleer and B. Sniderman, "The forces of change: Industry 4.0," Deloitte Insights, December, vol. 18, p. 2017, 2017.

[10] R. Geissbauer, J. Vedso, and S. Schrauf, "Industry 4.0: Building the digital enterprise," Retrieved from PwC Website: https://www. pwc. $\mathrm{com} / \mathrm{g} x / \mathrm{en} /$ industries/industries4.0/landing-page/industry-4.0building-your-digital-enterpriseapril-2016. pdf, 2016.

[11] C. J. Bartodziej, "The concept industry 4.0," in The Concept Industry 4.0, ed: Springer, 2017, pp. 27-50.

[12] S. J. Russell and P. Norvig, Artificial intelligence: a modern approach, 3rd ed. New Jersey: Prentice Hall, 2009.

[13] D. H. Autor, "Why are there still so many jobs? The history and future of workplace automation," Journal of Economic Perspectives, vol. 29, pp. 3-30, 2015. 
[14] K. Schwab, "The fourth industrial revolution," in World Economic Forum. New York: Crown Business, 2016.

[15] H. Boyes, B. Hallaq, J. Cunningham, and T. Watson, "The industrial internet of things (IIoT): An analysis framework," Computers in Industry, vol. 101, pp. 1-12, 2018.

[16] J. Guiochet, M. Machin, and H. Waeselynck, "Safety-critical advanced robots: A survey," Robotics and Autonomous Systems, vol. 94, pp. 43-52, 2017.

[17] F. Ingrand and M. Ghallab, "Deliberation for autonomous robots: A survey," Artificial Intelligence, vol. 247, pp. 10-44, 2017.

[18] V. Beal. (2016, 19 Agustus). Wearable technology. Available: https://www.webopedia.com/TERM/ W/wearable_technology.html

[19] W.-Y. Yeong, C.-K. Chua, K.-F. Leong, M. Chandrasekaran, and M.W. Lee, "Indirect fabrication of collagen scaffold based on inkjet printing technique," Rapid Prototyping Journal, vol. 12, pp. 229237, 2006.

[20] Q. Yan, H. Dong, J. Su, J. Han, B. Song, Q. Wei, et al., "A Review of 3D Printing Technology for Medical Applications," Engineering, 2018.

[21] Lee, "Building Toward a Modern Pharmaceutical Manufacturing Sector : Encouraging Development and Adoption of Emerging Technology," F. C. f. D. E. a. Research, Ed., ed. United States of America: FDA, 2015.

[22] S. Xue, P. Lv, Y. Wang, Y. Zhao, and T. Zhang, "Three dimensional bioprinting technology of human dental pulp cells mixtures," Journal of Peking University. Health sciences, vol. 45, pp. 105-108, 2013.

[23] J. W. Stansbury and M. J. Idacavage, "3D printing with polymers: Challenges among expanding options and opportunities," Dental Materials, vol. 32, pp. 54-64, 2016.

[24] J. Markarian. (2018, 6 Agustus 2018). Modernizing Pharma Manufacturing. Available:

http://www.pharmtech.com/moderniz ing-pharma-manufacturing

[25] S. C. Gad, Pharmaceutical manufacturing handbook: production and processes vol. 5: John Wiley \& Sons, 2008.

[26] S. Ibrić, Z. Đurić, J. Parojčić, and J. Petrović, "Artificial intelligence in pharmaceutical product formulation: neural computing," Chemical Industry and Chemical Engineering Quarterly, vol. 15, pp. 227-236, 2009.

[27] C. da Costa, C. Mendes, and R. Osaki, "Industry 4.0 In Automated Production," 2017.

[28] B. Ding, "Pharma industry 4.0: Literature review and research opportunities in sustainable pharmaceutical supply chains," Process Safety and Environmental Protection, vol. 119, pp. 115-130, 2018.

[29] S. A. Narayana, R. K. Pati, and P. Vrat, "Managerial research on the pharmaceutical supply chain-A critical review and some insights for future directions," Journal of Purchasing and Supply Management, vol. 20, pp. 18-40, 2014.

[30] R. Limaye, L. Kumar, and N Limaye, "Fourth generation technologies in pharmaceuticalsRevolutionizing healthcare," Journal of Systems Biology \& Proteome Research, vol. 2, 2018.

[31] S. J. Trenfield, A. Awad, A. Goyanes, S. Gaisford, and A. W. Basit, "3D printing pharmaceuticals: drug development to frontline care," Trends in pharmacological sciences, 2018.

[32] A. Goyanes, A. B. Buanz, G. B. Hatton, S. Gaisford, and A. W. Basit, "3D printing of modified-release aminosalicylate (4-ASA and 5-ASA) 
tablets," European Journal of

Pharmaceutics and

Biopharmaceutics, vol. 89, pp. 157-

162, 2015.

\section{BIOGRAFI PENULIS}

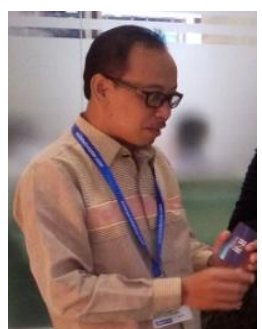

Dr. Suharman, SP.,M.Si lahir di Palembang pada tanggal 21 Maret 1969. Riwayat pendidikan, (S1) Teknologi Pertanian pada Fakultas Pertanian

Universitas Muhammadiyah Palembang lulus tahun 1994,(S2 dan S3) Teknologi Industri Pertanian Institut Pertanian Bogor masingmasing lulus tahun 1999 dan 2014. Riwayat pekerjaan, Dosen pada Fakultas Pertanian Universitas Muhammadiyah Palembang (1994-2002), Peneliti pada Baristand Industri Palembang (2002-2017) dan Peneliti pada Puslitbang TIKI, Kementerian Perindustrian RI (2017-sekarang).

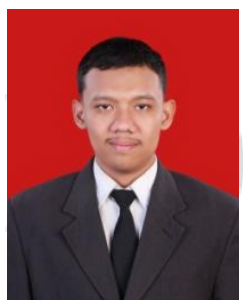

Hari Wisnu Murti, ST lahir di Sukoharjo pada tanggal 19 Maret 1994. Menempuh pendidikan S-1 di Departemen S-1 Teknik Kimia Universitas

Diponegoro pada tahun 2012 dan lulus pada tahun 2016. Diterima sebagai PNS di lingkungan Kementerian Perindustrian pada tahun 2018 dan saat ini menjabat sebagai Peneliti Ahli Pertama di Pusat Penelitian dan Pengembangan Industri Kimia, Farmasi, Tekstil, Logam, Mesin, Alat Transportasi, dan Elektronika. 